Róża Słowikl, Marta Wałaszekl,2, Witold Zieńczukl, Anna Różańska ${ }^{3}$, Jadwiga Wójkowska-Mach ${ }^{3}$, Matgorzata Kotpa ${ }^{1,2}$, Zdzistaw Wolak ${ }^{l, 2}$, Łukasz Kawik ${ }^{1}$

\title{
ANALYSIS OF THE INCIDENCE OF SURGICAL SITE INFECTIONS AFTER OPEN REPOSITION OF LONG BONE FRACTURES AND CLOSED FRACTURE SETTINGS IN A 7-YEAR FOLLOW-UP IN AN ORTHOPEDIC AND TRAUMA WARD IN SOUTHERN POLAND
}

\author{
ANALIZA WYSTĘPOWANIA ZAKAŻEŃ MIEJSCA OPEROWANEGO \\ PO ZABIEGACH OTWARTEJ REPOZYCJI ZŁAMAŃ KOŚCI DŁUGICH \\ I ZAMKNIĘTYCH NASTAWIENIACH ZŁAMAŃ W 7-LETNIEJ OBSERWACJI \\ W ODDZIALE ORTOPEDYCZNO-URAZOWYM W POLUDNIOWEJ POLSCE
}

\author{
${ }^{1}$ St. Luke's Provincial Hospital in Tarnów, \\ ${ }^{2}$ Poland State Higher Vocational School in Tarnów, \\ ${ }^{3}$ Department of Microbiology, Jagiellonian University, Kraków, Poland, Polish Society of Hospital Infections \\ ${ }^{1}$ Szpital Wojewódzki im. Św. Łukasza w Tarnowie, \\ ${ }^{2}$ Państwowa Wyższa Szkoła Zawodowa w Tarnowie, \\ ${ }^{3}$ Uniwersytet Jagielloński w Krakowie, Katedra Mikrobiologii, Polskie Towarzystwo Zakażeń Szpitalnych
}

\begin{abstract}
INTRODUCTION. Surgical Site Infection (SSI) is the most common clinical form of Healthcare-Associated Infections (HAI) in orthopedic and trauma wards.

MATERIAL AND METHOD. A retrospective study was conducted at the Department of Orthopedics and Trauma Surgery in Tarnów in 2012-2018. 3155 patients treated for bone fractures were analyzed, including 1961 Open Reduction of Fracture (FX) and 1194 Closed Reduction of Fracture with Internal Fixation (CR) surgeries. The study was conducted in accordance with the methodology recommended by the Surveillance Network (HAI-Net), European Centre for Disease Prevention and Control (ECDC). The aim of the study was to assess the incidence of SSI in patients undergoing the FX and CR procedures.

RESULTS. 28 SSIs were identified in the examined ward; 16 SSI cases related to the FX procedure and 12 cases related to CR. The incidence for FX was $0.8 \%$ and for CR $1 \%$. In patients with diagnosed SSI, the stay in the ward was longer $(\mathrm{p}<0.001)$ than in patients without SSI. In FX operations, the standardized risk index (SIR) did not exceed the value of one. Staphylococcus aureus was the most common organism isolated from materials from patients with SSI.

CONCLUSIONS. In the examined period, the median age of women was higher than that of men, which may indicate a higher incidence of fractures in women. Patients with diagnosed SSI had a longer stay in the ward than patients without SSI. The incidence of SSI in FX and CR has been reduced compared to previous studies in the same ward.
\end{abstract}

Key words: orthopedics, open reposition of fracture or dislocation of long bones, Surgical Site Infection, closed fracture setting.

\section{STRESZCZENIE}

WSTĘP. Zakażenia miejsca operowanego (Surgical Site Infection - SSI) są najczęstszą formą kliniczną zakażeń szpitalnych (Healthcare-Associated Infections - HAI) w oddziałach ortopedyczno - urazowych.

MATERIAŁ I METODY. Badanie retrospektywne zostało przeprowadzone w Oddziale Ortopedyczno-Urazowym w Tarnowie w latach 2012-2018. Analizie poddano 3155 pacjentów leczonych z powodu złamań kości,

C National Institute of Public Health - National Institute of Hygiene / Narodowy Instytut Zdrowia Publicznego - Państwowy Zakład Higieny 
w tym 1961 otwartych repozycji złamania kości długich (Open Reduction of Fracture - FX) i 1194 zamkniętych repozycji złamań kości (Closed Reduction of Fracture with Internal Fixation - CR). Badanie zostało przeprowadzone zgodnie z metodyką rekomendowaną przez Surveillance Network (HAI-Net) European Center for Disease Prevention and Control (ECDC). Celem badania była ocena zapadalności na SSI u pacjentów poddanych procedurze FX i CR.

WYNIKI. W badanym oddziale rozpoznano 28 SSI; 16 przypadków SSI związanych z procedurą FX i 12 przypadków związanych z CR. Zapadalność dla FX wynosiła $0,8 \%$, a dla CR $1 \%$. U pacjentów z rozpoznanym SSI pobyt $w$ oddziale był dłuższy $(p<0,001)$ niż pacjentów bez SSI. W operacjach FX standaryzowany indeks ryzyka (SIR) nie przekroczył wartości jeden. Najczęstszym drobnoustrojem izolowanym z materiałów pochodzących od pacjentów z SSI był Staphylococcus aureus.

WNIOSKI. W badanym okresie mediana wieku kobiet była wyższa niż mężczyzn, co może wskazywać na częstsze występowanie złamań u kobiet. Pacjenci z rozpoznanym SSI mieli dłuższy pobyt w oddziale niż pacjenci bez SSI. Zapadalność na SSI w FX i CR uległa zmniejszeniu w porównaniu z wcześniejszymi badaniami prowadzonymi w tym samym oddziale.

Slowa kluczowe: ortopedia, otwarta repozycja złamania lub zwichnięcia kości dtugich, Surgical Site Infection, zamknięte nastawienie złamania

\section{LIST OF ABBREVIATIONS}

ASA (American Society of Anesthesiologists) - scale of surgical risk, CR (Closed Reduction of Fracture with Internal Fixation) - zamknięte nastawienie złamania ze stabilizacją wewnętrzną, ECDC (European Centre for Disease Prevention and Control) - Europejskie Centrum ds. Zapobiegania i Kontroli Chorób, FX (Open Reduction of Fracture) - otwarta repozycja złamania lub zwichnięcia kości długich, GUS Główny Urząd Statystyczny (Central Statistical Office), HAI (Healthcare-Associated Infections) zakażenie szpitalne, HAI-Net (Healthcare-Associated Infections Surveillance Network) - zakażenie szpitalne, ICD 9 (International Classification of Diseases) Międzynarodowa Klasyfikacja Procedur Medycznych, $\mathrm{W}$ - women, $\mathrm{M}$ - men, Me - median, NFZ - Narodowy Fundusz Zdrowia (National Health Fund), NHSN (National Healthcare Safety Network) - Narodowy Program Bezpieczeństwa w Opiece Zdrowotnej w USA, SD - standard deviation, SIR (Standardized Infection Ratio) - Standaryzowany Indeks Ryzyka, SSI (Surgical Site Infection) - zakażenia miejsca operowanego, SSI-D (Deep Surgical Site Infection) - zakażenia miejsca operowanego głębokie, SSI-O (Organ/Space Surgical Site Infection) - zakażenia narządu/jamy ciała, SSI-S (Superficial Surgical Site Infection) - zakażenia miejsca operowanego powierzchowne, W3 - contaminated operating field, W4 - dirty operating field.

\section{INTRODUCTION}

Healthcare-associated infections (HAIs), which include surgical site infections (SSIs), are still an ongoing problem in healthcare facilities, especially for surgical wards, in which they are the most common clinical form of HAIs for these wards.

\section{WYKAZ SKRÓTÓW}

ASA (American Society of Anesthesiologists) skala ryzyka operacyjnego, CR (Closed Reduction of Fracture with Internal Fixation) - zamknięte nastawienie złamania ze stabilizacją wewnętrzną, ECDC (European Center for Disease Prevention and Control) - Europejskie Centrum ds. Zapobiegania i Kontroli Chorób, FX (Open Reduction of Fracture) - otwarta repozycja złamania lub zwichnięcia kości długich, GUS - Główny Urząd Statystyczny, HAI (Healthcare-Associated Infections) - zakażenie szpitalne, HAINet (Net - Healthcare-Associated Infections Surveillance Network) - zakażenie szpitalne, ICD 9 (International Classification of Diseases) - Międzynarodowa Klasyfikacja Procedur Medycznych, K - kobiety, M - mężczyźni, Me - mediana, NFZ - Narodowy Fundusz Zdrowia, NHSN (National Healthcare Safety Network) - Narodowy Program Bezpieczeństwa w Opiece Zdrowotnej w USA, SD - odchylenie standardowe, SIR (Standardized Infection Ratio) - Standaryzowany Indeks Ryzyka, SSI (Surgical Site Infection) - zakażenia miejsca operowanego, SSI-D (Deep Surgical Site Infection) - zakażenia miejsca operowanego głębokie, SSI-O (Organ/Space Surgical Site Infection) - zakażenia narządu/jamy ciała, SSI-S (Superficial Surgical Site Infection) - zakażenia miejsca operowanego powierzchowne, W3 - miejsce operowane skażone, W4 - miejsce operowane brudne.

\section{WSTEP}

Healthcare-Associated Infections (HAI), do których należą zakażenia miejsca operowanego (surgical site infection $\mathrm{SSI}$ ) są wciąż aktualnym problemem w placówkach medycznych, zwłaszcza dla oddziałów zabiegowych, gdzie są najczęstszą formą kliniczną 
The development of SSI is influenced by many risk factors, which can be divided into: (a) patient-related factors, (b) environment-related factors, and (c) factors associated with the type of surgical procedure (1-3). The specificity of orthopedic and trauma wards is the treatment of patients with fractures of long bones resulting from traffic accidents, doing sports or everyday life injuries. These, sometimes extremely complicated, fractures result in the need for a flexible approach to their treatment and continuous improvement in relation to surgical instruments. The employment of biomaterial implants in the treatment of fractures allows doctors to perform more and more complicated surgeries, however, it also increases the risk of SSI. The commonly used intramedullary osteosynthesis is a therapeutic method that accelerates the return to mobility, shortens the patient's hospital stay, and reduces the risk of complications; however, it does not eliminate SSI (4-5). According to the global literature, the general incidence of SSI in orthopedic wards ranges from $0.7 \%$ to $22.7 \%$ (6-9). On the other hand, the Polish literature reports the incidence of SSI for these wards as ranging from $1.3 \%$ to $6.6 \%$ (10-12). As regards the latter, there was only one study on the incidence of SSI in open reduction of fracture (FX) and closed reduction of fracture (CR) and the rates were from $5 \%$ to $10 \%$ in $\mathrm{FX}$ and from $2 \%$ to $9 \%$ in CR (13).

The aim of the study was to evaluate the incidence of surgical site infections in patients subjected to FX and $\mathrm{CR}$ procedures.

\section{MATERIAL AND METHODS}

The study on SSI was carried out at the Department of Orthopedics and Trauma Surgery of St. Luke's Provincial Hospital in Tarnów in 2012-2018. Active surveillance of SSIs was commenced in the ward under study in 2002 and some research involving the ward has already been published (14). Active surveillance was employed to collect patient data. The supervision of SSIs was conducted by the members of the infection control team that is active in the hospital (nurse epidemiologists, physician, microbiologist). Moreover, each SSI detected was analyzed by the individual case method and consulted with a physician of the examined Department of Orthopedics and Trauma Surgery. The hospital under study participates in the voluntary nationwide system of active registration of hospital infections, conforming to the methodology of the Healthcare-associated Infections Surveillance Network (HAI-Net), European Centre for Disease Prevention and Control (ECDC) (15-16). The surgical procedures performed were subjected to analysis and classified according to the International Classification
HAI dla tych oddziałów. Na powstawanie SSI ma wpływ wiele czynników ryzyka, które można podzielić na: (a) czynniki ze strony pacjenta, (b) związane ze środowiskiem (c) rodzajem procedury operacyjnej (1-3). Specyfiką oddziałów ortopedyczno-urazowych jest leczenie pacjentów ze złamaniami kości długich, powstałych w wyniku wypadków komunikacyjnych, uprawiania sportu czy urazów wynikających z życia codziennego. Efekty tych złamań, niekiedy bardzo skomplikowanych, powodują konieczność elastycznego podejścia do sposobu ich leczenia i ciągłego doskonalenia w zakresie instrumentarium chirurgicznego. Stosowanie w leczeniu złamań implantów z biomateriałów daje możliwość wykonania coraz bardziej skomplikowanych operacji, ale również zwiększa ryzyko SSI. Powszechnie stosowana osteosynteza śródszpikowa jest metodą terapeutyczną, która przyspiesza powrót do sprawności ruchowej, skraca pobyt pacjenta w oddziale, zmniejsza ryzyko powikłań, jednak nie eliminuje SSI (4-5). W literaturze światowej w oddziałach o profilu ortopedycznym ogólna zapadalność na SSI podawana jest w zakresie od $0,7 \%$ do $22,7 \%$ (6-9). W polskiej literaturze można znaleźć zapadalność na SSI dla tych oddziałów na poziomie od $1,3 \%$ do $6,6 \%$ (10-12). W literaturze polskiej znaleziono tylko jedno badanie pokazujące zapadalność na SSI w otwartych repozycjach złamań kości długich (FX) i w zamkniętych nastawieniach złamania (CR), wskaźnik ten wynosił od 5\% do 10\% w FX, i od 2\% do 9\% w CR (13).

Celem badania była ocena zapadalności na zakażenia miejsca operowanego u pacjentów poddanych procedurze FX i CR.

\section{MATERIAŁ I METODY}

Badanie nad SSI prowadzono w oddziale ortopedyczno-urazowym w Szpitalu Wojewódzkim im. Św. Łukasza w Tarnowie w latach 2012-2018. Aktywny nadzór nad zakażeniami SSI w badanym oddziale rozpoczął się w roku 2002, a badania dotyczące oddziału były już przedmiotem publikacji (14). Dane o pacjentach zebrano metodą czynnego nadzoru. Nadzór nad SSI prowadzili członkowie zespołu kontroli zakażeń działający w strukturach szpitala (pielęgniarki epidemiologiczne, lekarz, mikrobiolog). Ponadto każde wykryte SSI analizowano metodą indywidualnego przypadku oraz konsultowano z lekarzem badanego oddziału ortopedyczno - urazowego. Szpital, w którym wykonano badanie uczestniczy w dobrowolnym ogólnopolskim systemie czynnej rejestracji zakażeń szpitalnych, zgodnym z metodyką Healthcare-associated Infections Surveillance Network (HAI-Net) European Center for Disease Prevention and Control (ECDC) (15-16). Przeprowadzone zabiegi operacyjne poddano analizie i sklasyfikowano według procedury 
of Diseases (ICD 9): FX - 79.21; 79.22; 79.25; 79.26; $79.31 ; 79.32 ; 79.35 ; 79.36 ; 79.51 ; 79.52 ; 79.55 ; 79.56$ and CR - 79.11-79.18; 79.191-79.1. In the course of the study, surgical site infections were classified according to the classification adopted in surveillance: superficial (SSI-S), deep (SSI-D) and organ/space (SSI-O), however, in practice, only SSI-D were detected (the remaining types of SSI were not present). Microbiological tests examined material, i.e. swabs or intraoperative samples, obtained from patients and each isolated microorganism was identified in the Vitek 2 Compact automated system.

As regards epidemiological indicators, the incidence rate of SSI was calculated and analysis was carried out for variables such as: sex, age, waiting time for surgery in the ward, duration of stay in the ward, number of days from surgery to SSI detection. The incidence rate was calculated as the number of cases of SSI per 100 operations. The standardized infection ratio (SIR) for SSI was also calculated which, according to the National Healthcare Safety Network (NHSN), consists of 3 variables affecting the probability of SSI; these concern: (a) the degree of cleanliness of the operating field, (b) duration of surgery, (c) evaluation of the patient's condition according to the American Society of Anesthesiologists (ASA) risk score. The degree of cleanliness of the operating field is determined by the surgeon during the treatment. 1 point is assigned for a contaminated (W3) or dirty (W4) surgical site. Moreover, 1 point is given to patients whose duration of surgery exceeds the $75^{\text {th }}$ percentile. The ASA score was evaluated by an anesthesiologist prior to the surgery and 1 point was given when the ASA score was 3 or more. SIR can therefore range from 0 to 3 , and when it reaches more than 1, it means that there were more SSIs than expected (16).

Statistical analysis of the collected material employed the following software: IBM SPSS (SPSS - Statistical Package for the Social Sciences) STATISTICS 24, Armonk, NY, USA and Microsoft Excel, Microsoft Office 2016, Redmond, WA, USA. The study made use of the following statistical indicators: arithmetic mean, median, standard deviation, and $95 \%$ confidence interval. To compare the frequency of occurrence of qualitative feature variants, Pearson's chi-square test of independence was used and ANOVA was employed for quantitative variables.

The use of data was approved by the Bioethical Committee of the Jagiellonian University (No. KBET /122.6120.118.2016 from 25.05.2016). All the data entered into the electronic database and analyzed in this study was previously anonymized.
International Classification of Disease (ICD 9): FX $79.21 ; 79.22 ; 79.25 ; 79.26 ; 79.31 ; 79.32 ; 79.35 ; 79.36$; $79.51 ; 79.52$; 79.55; 79.56 i CR - 79.11-79.18; 79.19179.1. W trakcie badania zakażenia miejsca operowanego klasyfikowano według przyjętej w nadzorze klasyfikacji na: powierzchniowe (SSI-S), głębokie (SSI-D) i organu (SSI-O), jednak w praktyce wykryto tylko SSI-D (pozostałe typy SSI nie wystąpiły). Do badań mikrobiologicznych użyto materiału pozyskanego od pacjentów w postaci wymazu z rany lub próbki śródoperacyjnej, a każdy wyizolowany drobnoustrój identyfikowano w automatycznym systemie Vitek 2 Compact.

Wśród wskaźników epidemiologicznych wyliczono współczynnik zapadalności na SSI oraz dokonano analizy zmiennych takich jak: płeć, wiek, czas oczekiwania na operację w oddziale, czas pobytu w oddziale, liczba dni od operacji do wykrycia SSI. Współczynnik zapadalności wyliczono, jako liczbę przypadków SSI per 100 operations. Wyliczono również Standaryzowany Indeks Ryzyka wystapienia SSI (Standardized Infection Ratio - SIR), który wg. National Healthcare Safety Network (NHSN) składa się z 3 zmiennych wpływających na prawdopodobieństwo SSI, dotyczą one; (a) stopnia czystości pola operacyjnego, (b) czasu trwania operacji, (c) oceny pacjenta w skali ryzyka operacyjnego American Society of Anesthesiologists (ASA). Stopień czystości pola operacyjnego określa lekarz operujący w czasie zabiegu, gdzie 1 punkt przyznaje się za miejsce operowane skażone (W3) lub brudne (W4). Kolejno 1 punkt otrzymuje pacjent, gdy czas trwania operacji przekracza 75 percentyli. Ocenę stopnia skali ASA dokonywał anestezjolog przed operacją i 1 punkt był przyznawany, gdy skala ASA wynosiła 3 lub więcej. SIR może więc wynosić od 0 do 3 , gdy SIR osiągnie więcej niż 1, oznacza, że wystąpiło więcej SSI niż zakładano (16).

W analizie statystycznej zebranego materiału użyto programu statystycznego IBM SPSS (SPSS - Statistical Package for the Social Sciences) STATISTICS 24, Armonk, NY, USA oraz Microsoft Excel Microsoft Office 2016 Redmond, WA, USA. W badaniu użyto wskaźników statystycznych, tj.: średnia arytmetyczna, mediana, odchylenie standardowe, 95\% przedział ufności. W celu porównania częstości występowania wariantów cechy jakościowej zastosowano test niezależności chi-kwadrat Pearsona oraz test ANOVA dla zmiennych ilościowych.

The use of data was approved by the Bioethical Committee of the Jagiellonian University (No. KBET /122.6120.118.2016 from 25.05.2016). All the data entered into the electronic database and analyzed in this study was previously anonymised. 


\section{RESULTS}

During the 7 years of the study, the total number of surgery patients in the Department of Orthopedics and Trauma Surgery who were included in the research amounted to 3,155. FX surgeries were performed in 1,961 patients whose median age was 62 years $(72$ years for women $[\mathrm{W}], 50$ years for men $[\mathrm{M}])$. Women underwent these surgeries more often: $56.7 \%$ (W) vs $43.3 \%$ (M). CR procedures were conducted in 1,194 patients whose median age was 60 years ( 70 years for $\mathrm{W}, 40$ years for $\mathrm{M}$ ). The percentage share of women and men in these operations was comparable: $50.6 \%$ vs $49.4 \%$, respectively (Tab. 1).
WYNIKI

W okresie 7 lat w badanym oddziale ortopedyczno-urazowym całkowita liczba operowanych pacjentów objętych badaniem wynosiła 3155 osób. Operacje FX wykonano u 1961 pacjentów, ich mediana wieku wynosiła 62 lata (72 lata dla kobiet (K), 50 lat dla mężczyzn (M)), operacjom tym częściej były poddawane kobiety $56,7 \%(\mathrm{~K})$ vs $43,3 \%(\mathrm{M})$. Operacje typu CR przeprowadzono u 1194 pacjentów, mediana wieku wynosiła 60 lat (70 lat $\mathrm{K}, 40$ lat dla $\mathrm{M}$ ), procentowy udział kobiet i mężczyzn w tych operacjach był porównywalny $50,6 \%$ vs $49,4 \%$ (Tab. I).

Table 1. Demographic characteristics of patients including the type of surgery and the sex of patients in 2012-2018

Tabela I. Charakterystyka demograficzna pacjentów z uwzględnieniem typu operacji oraz płci pacjentów w latach 20122018

\begin{tabular}{|c|c|c|}
\hline Surgery type/ Typ operacji & FX & $\mathrm{CR}$ \\
\hline Number of surgeries/ Liczba operacji & 1961 & 1194 \\
\hline \multicolumn{3}{|c|}{ Patient age [years]/ Wiek pacjentów [lata] } \\
\hline Mean/ Średnia $(95 \% \mathrm{Cl})$ & $60(59-61)$ & $55(53-56)$ \\
\hline Median/Mediana & 62 & 60 \\
\hline Standard deviation/ Odchylenie standardowe & 21,5 & 25,5 \\
\hline \multicolumn{3}{|c|}{ Women's age on the day of surgery [years]/ Wiek kobiet $w$ dniu operacji [lata] } \\
\hline Mean/ Średnia $(95 \% \mathrm{Cl})$ & $69(68-70)$ & $66(64-67)$ \\
\hline Median/Mediana & 72 & 70 \\
\hline Standard deviation/ Odchylenie standardowe & 18,5 & 21,8 \\
\hline \multicolumn{3}{|c|}{ Men's age on the day of surgery [years] / Wiek mężczyzn w dniu operacji [lata] } \\
\hline Mean/ Średnia $(95 \% \mathrm{Cl})$ & $50(48-51)$ & $43(41-45)$ \\
\hline Median/Mediana & 50 & 40 \\
\hline Standard deviation/ Odchylenie standardowe & 21,3 & 24 \\
\hline \multicolumn{3}{|l|}{ Patient sex [n (\%)]/ Płeć pacjentów [n (\%)] } \\
\hline Woman/ Kobieta & $1111(56,7)$ & $604(50,6)$ \\
\hline Man/Mężczyzna & $850(43,3)$ & $590(49,4)$ \\
\hline Total/ Razem & $1961(100)$ & $1194(100)$ \\
\hline
\end{tabular}

In this study, 16 cases of SSI-D were detected in FX surgeries (the incidence per 100 operations amounted to $0.8 \%$ ). In CR operations, 12 cases of SSI were detected (incidence of $1 \%$ ). The average length of hospital stay for patients was: 8 days for FX (Me 7, SD 7.0) and 6 days for CR (Me 5, SD 5.4). On the other hand, the waiting time for surgery in the ward was 2 days for FX (Me 2, SD 4.0) and 2 days for CR (Me 1, SD 2.6). As for both types of surgery, patients who were diagnosed with SSI stayed in the ward longer than patients without SSI: 10 days with SSI vs 7 days without SSI for FX $(\mathrm{p}<0.001) ; 10$ days with SSI vs 5 days without SSI for CR $(\mathrm{p}<0.001)$. The median duration of surgery was 70 minutes for FX procedures and 50 minutes for CR operations (Tab. 2).
W niniejszym badaniu wykryto 16 przypadków SSI-D w operacjach FX (zapadalność na 100 operacji wynosiła $0,8 \%$ ). W operacjach CR wykryto 12 przypadków SSI (zapadalność 1\%). Średni czas pobytu pacjentów wynosił: dla operacji FX 8 dni (Me 7, SD 7,0) a dla CR 6 dni (Me 5, SD 5,4). Natomiast czas oczekiwania na operację w oddziale w operacjach FX wynosił 2 dni (Me 2, SD 4,0), a w CR 2 dni (Me 1, SD 2,6). W obu typach operacji pacjenci, u których wykryto SSI przebywali dłużej w oddziale niż pacjenci bez SSI: FX 10 dni z SSI vs 7 dni bez SSI $(p<0,001)$; CR 10 dni z SSI vs 5 dni bez SSI $(p<0,001)$. W operacjach FX mediana czasu trwania operacji wynosiła 70 minut, a w operacjach CR 50 min (Tab. II). 
Table 2. FX and CR operations and variables such as: incidence, length of stay in the ward, waiting time for surgery, duration of surgery (2012-2018)

Tabela II. Operacje FX i CR oraz zmienne takie jak: zapadalność, czas pobytu w oddziale, czas oczekiwania na operację, czas trwania operacji, w latach 2012-2018

\begin{tabular}{|c|c|c|}
\hline Surgery type/ Typ operacji & FX & $\mathrm{CR}$ \\
\hline Number of surgeries/ Liczba operacji & 1961 & 1194 \\
\hline All SSI & 16 & 12 \\
\hline Incidence of SSI/ Zapadalność na SSI & 0,8 & 1 \\
\hline \multicolumn{3}{|c|}{ SSI type/ Typ SSI } \\
\hline SSI-D (n) & 16 & 12 \\
\hline \multicolumn{3}{|c|}{ Length of stay in the ward [days]/ Czas pobytu w oddziale [dni] } \\
\hline Mean/ Średnia $(95 \% \mathrm{Cl})$ & $8(8-9)$ & $6(6-7)$ \\
\hline Median/ Mediana & 7 & 5 \\
\hline Standard deviation/ Odchylenie standardowe & 7 & 5,4 \\
\hline \multicolumn{3}{|c|}{ Waiting time for surgery in the ward [days]/ Czas oczekiwania na operację w oddziale [dni] } \\
\hline Mean/ Średnia $(95 \% \mathrm{Cl})$ & $2(2-3)$ & $2(2-2)$ \\
\hline Median/ Mediana & 2 & 1 \\
\hline Standard deviation/ Odchylenie standardowe & 4 & 2,6 \\
\hline \multicolumn{3}{|c|}{ Duration of surgery [minutes]/ Czas trwania operacji [minuty] } \\
\hline Mean/Średnia & $77(74-79)$ & $53(50-56)$ \\
\hline Median/ Mediana & 70 & 50 \\
\hline Standard deviation/ Odchylenie standardowe & 43,9 & 32,8 \\
\hline \multicolumn{3}{|c|}{$\begin{array}{l}\text { Length of stay in the ward for patients with and without SSI [days]/ Liczba dni pobytu pacjentów z SSI i bez SSI } \\
\text { w oddziale }\end{array}$} \\
\hline Type of surgery/ Typ operacji & FX & $\mathrm{CR}$ \\
\hline Patients with SSI (days)/ Pacjenci z SSI (dni) & 10 & 10 \\
\hline Patients without SSI (days)/ Pacjenci bez SSI (dni) & 7 & 5 \\
\hline ANOVA test of significance/ Test istotności ANOVA & $\mathrm{p}<0,001$ & $\mathrm{p}<0,001$ \\
\hline$(95 \% \mathrm{CI})-95 \%$ confidence interval for the mean/ prze & i dla średni & \\
\hline
\end{tabular}

The Standardized Infection Ratio for SSI was calculated for FX; the incidence was as follows: 1.7\% without risk factors and $1 \%$ with one risk factor. The obtained test results were compared to NHSN (20062008). In our study, SIR exceeded the value of over 1 (amounted to 1.7) for FX without risk factors, which means that the incidence of SSI was higher than expected. In CR surgeries, the following incidence was found: $1.0 \%$ without risk factors, $0.7 \%$ with one risk factor and $4.9 \%$ for surgeries with 2 risk factors (SIR for CR did not exceed 1 [Table 3]).

Gram-positive bacteria dominated among the etiologic agents isolated from patients with SSI for FX and CR; Staphylococcus aureus comprised $23.5 \%$ for FX, and $40 \%$ for CR (Table 4).

\section{DISCUSSION}

In the ward under study, FX surgeries were among the ones most frequently performed. A difference was discovered regarding the age of surgery patients in
Wyliczono Standaryzowany Indeks Ryzyka SSI dla FX, zapadalność wynosiła kolejno: 1,7\% bez czynników ryzyka, $1 \%$ z jednym czynnikiem ryzyka. Uzyskane wyniki badań porównano z NHSN (2006-2008). W naszych badaniach SIR przekroczył wartość powyżej 1 (wynosił 1,7) dla FX bez czynników ryzyka, co oznacza, że zapadalność na SSI była wyższa od oczekiwanej. W operacjach CR uzyskano zapadalność: $1,0 \%$ bez czynników ryzyka, $0,7 \%$ z jednym czynnikiem ryzyka i 4,9\% dla operacji z 2 czynnikami ryzyka (SIR dla CR nie przekroczyła wartości jeden (Tab. III).

Wśród czynników etiologicznych izolowanych od pacjentów z SSI dla FX i CR dominowały bakterie Gram-dodatnie; Staphylococcus aureus stanowiący 23,5\% dla FX, a dla CR 40\% (Tab. IV).

\section{DYSKUSJA}

W badanym oddziale operacje typu FX należały do jednych z najczęściej wykonywanych. Odkryto różnicę dotyczącą wieku operowanych pacjentów w tym 
Table 3. Incidence of SSI in FX and CR in the examined Orthopedics and Trauma Surgery ward in comparison with NHSN (2006-2008) [19] and [10] (2008-2012) considering risk factors (2012-2018)

Tabela III. Zachorowalność na SSI dla FX i CR w badanym oddziale ortopedyczno-urazowym w porównaniu z NHSN (2006-2008) [19] i [10] (2008-2012) z uwzględnieniem czynników ryzyka, w okresie 2012-2018

\begin{tabular}{|c|c|c|c|c|c|c|c|}
\hline $\begin{array}{l}\text { Procedure } \\
\text { type/ } \\
\text { Typ } \\
\text { zabiegu }\end{array}$ & $\begin{array}{l}\text { Risk factors/ } \\
\text { Czynniki ryzyka }\end{array}$ & $\begin{array}{c}\text { Number } \\
\text { of } \\
\text { surgeries } \\
\text { Liczba } \\
\text { operacji }\end{array}$ & $\begin{array}{c}\text { Number } \\
\text { of SSIs/ } \\
\text { Liczba } \\
\text { SSI }\end{array}$ & $\begin{array}{c}\text { Incidence in the } \\
\text { examined ward } \\
(\%) / \\
\text { Zachorowalność } \\
\text { w badany } \\
\text { oddziale }(\%)\end{array}$ & $\begin{array}{l}\text { NHSN } \\
\text { incidence [19] } \\
(\text { FX) and }[10] \\
\text { (CR) }(\%) / \\
\text { Zachorowalność } \\
\text { NHSN [19] (FX) } \\
\text { i [10] (CR) }(\%) \\
\end{array}$ & $\begin{array}{c}\text { Expected } \\
\text { number of } \\
\text { SSIs/ } \\
\text { oczekiwana } \\
\text { liczba SSI }\end{array}$ & SIR* SSI \\
\hline \multirow{3}{*}{ FX } & $\begin{array}{l}\text { No risk factors/ } \\
\text { Brak czynników ryzyka }\end{array}$ & 630 & 11 & 1,7 & 1,1 & 7 & 1,6 \\
\hline & $\begin{array}{l}1 \text { risk factor/ } \\
1 \text { czynnik ryzyka }\end{array}$ & 483 & 5 & 1 & 1,8 & 9 & 0,6 \\
\hline & $\begin{array}{l}2 \text { and } 3 \text { risk factors/ } \\
2 \text { i } 3 \text { czynniki ryzyka }\end{array}$ & 80 & 0 & 0 & 3,4 & 3 & 0 \\
\hline \multirow{3}{*}{$\mathrm{CR}$} & $\begin{array}{l}\text { No risk factors/ } \\
\text { Brak czynników ryzyka }\end{array}$ & 724 & 7 & 1,0 & 1,8 & 13 & 0,5 \\
\hline & $\begin{array}{l}1 \text { risk factor/ } \\
1 \text { czynnik ryzyka }\end{array}$ & 429 & 3 & 0,7 & 1,6 & 7 & 0,4 \\
\hline & $\begin{array}{l}2 \text { and } 3 \text { risk factors/ } \\
2 \text { i } 3 \text { czynniki ryzyka }\end{array}$ & 41 & 2 & 4,9 & 6,3 & 3 & 0,8 \\
\hline \multicolumn{8}{|c|}{$\begin{array}{l}\text { SIR*SSI - Standardized Infection Ratio for SSI, *Expected number of SSIs was calculated according to the formula }= \\
\text { cumulative incidence rate of SSI in the NHSN program (FX) [19] and [10] (CR) x number of (own) surgeries performed } \\
\text { / 100. SIR for SSI was calculated according to the formula = number of SSIs detected / number of expected SSIs. SSI - } \\
\text { surgical site infection/ } \\
\text { SIR*SSI - Standaryzowany Indeks Ryzyka SSI, *Oczekiwana liczba SSI została wyliczona wg wzoru = zachorowalność } \\
\text { skumulowana SSI w programie NHSN (FX) [19] i [10] (CR) x liczba wykonanych operacji (własnych) / 100. SIR dla SSI } \\
\text { wyliczono wg wzoru = liczba wykrytych SSI / liczba oczekiwanych SSI. SSI - zakażenie miejsca operowanego, }\end{array}$} \\
\hline
\end{tabular}

Table 4. Microorganisms isolated from patients with SSI during FX and CR operations in 2012-2018

Tabela IV. Drobnoustroje izolowane od pacjentów z SSI w operacjach FX i CR w latach 2012-2018

\begin{tabular}{|l|c|c|c|}
\hline \multicolumn{1}{|c|}{$\begin{array}{c}\text { Microorganism/ } \\
\text { Drobnoustrój }\end{array}$} & $\mathrm{FX}$ & $\mathrm{CR}$ & Total/ Ogółem \\
\cline { 2 - 4 } & $\mathrm{n} \mathrm{( \% )}$ & $\mathrm{n} \mathrm{( \% )}$ & $\mathrm{n}(\%)$ \\
\hline Staphylococcus aureus & $4(23.5)$ & $4(40.0)$ & $8(29.6)$ \\
\hline Coagulase-negative Staphylococcus & $1(5.9)$ & $1(10.0)$ & $2(7.4)$ \\
\hline Klebsiella pneumoniae & $1(5.9)$ & & $1(3.7)$ \\
\hline Enterococcus faecalias & $2(11.8)$ & & $2(7.4)$ \\
\hline Enterobacter cloacae & $1(5.9)$ & $2(20.0)$ & $3(11.1)$ \\
\hline Escherichia coli & $1(5.9)$ & $1(10.0)$ & $2(7.4)$ \\
\hline Proteus mirabilis & $1(5.9)$ & $1(10.0)$ & $2(7.4)$ \\
\hline Klebsiella oxytoca & $1(5.9)$ & & $1(3.7)$ \\
\hline Enterbacter aerogenes & $1(5.9)$ & & $1(3.7)$ \\
\hline Pseudomonas aeruginosa & $1(5.9)$ & & $1(3.7)$ \\
\hline Streptococcus sanguis & $1(5.9)$ & & $1(3.7)$ \\
\hline Not isolated/ Nie izolowano & $2(11.8)$ & $1(10.0)$ & $3(11.1)$ \\
\hline Total/ Ogółem & 17 & 10 & 27 \\
\hline
\end{tabular}

relation to this type of operation; in this study (20122018), the mean age of surgery patients undergoing FX was 60 years, while in the previous study (20082012), the mean was 52 years (10). On the basis of this typie operacji, w obecnym badaniu (lata 2012-2018) średnia wieku operowanych FX pacjentów wynosiła 60 lat, a we wcześniejszych badaniach (lata 20082012) średnia 52 lata (10). Na podstawie tej obserwacji 
observation, a tentative hypothesis can be put forward that the health condition of the residents of Tarnów and the region is improving as regards the length of time lived in good health (without fractures). It is worthwhile to mention that, in FX surgeries, the proportion of women was higher than that of men. The women's age suggests that fractures in this group occur after menopause. The data from the National Health Fund (NFZ) and the Central Statistical Office of Poland (GUS) indicate that, in Poland in 2014, 63 osteoporosis outpatient clinics received contracts, of which 1 was in the Małopolska Province (17). Hence, perhaps this has to do with the availability of osteoporosis treatment for women. Nevertheless, the literature does not offer other studies exemplifying the issue studied. 16 cases of SSI in FX procedures were identified in the examined ward (incidence of $0.8 \%$ ). Previous research carried out by Wataszek et al. (10) in the same ward (2008-2012) detected a much higher incidence of 3.4\%. While other Polish studies conducted by WojkowskaMach et al. (18) reveal the incidence of SSI regarding FX of $1.6 \%$. In the ward under study, the incidence of SSI for FX taking into account variables typical of SSI (degree of operating field cleanliness, duration of surgery, ASA score) amounted to: $1.7 \%$ (without risk factors); $1 \%$ ( 1 risk factor); $0 \%$ ( 2 and 3 risk factors). In the analyses carried out by Wałaszek et al. (10) in the same ward in 2008-2012, it amounted to, respectively: $2 \% ; 2.6 \% ; 10.3 \%$. In another Polish study, carried out in 2003-2004, the mean incidence of SSI in FX was as follows: $1.1 \%$ (without risk factors), $0.5 \%$ (1 risk factor), $21.4 \%$ (2 and more risk factors) (18). Incidence indices of SSI in FX obtained in our study were compared with the rates obtained under the US NHSN program 2006-2008 (19) and gave a SIR value that exceeded one (SIR 1.6) in surgeries without risk factors. The present index is, however, lower than the one obtained in the earlier study of the same ward for surgeries without risk factors, i.e. SIR 1.6 (2012-2018) vs SIR 3.2 (2008-2012). This situation can be cautiously interpreted as a reduction in the incidence of SSI in FX as a result of surveillance. And while it is difficult to list specific actions that were undertaken which resulted in reducing the incidence, it can be suggested that the simple act of summarizing the outcome of the surveillance in the previous study (10) and the involvement of the examined ward in the prevention of SSI could have contributed to the reduction.

In the analysis of CR surgeries in the ward under study, it was discovered that, similarly to the previous type of surgery, also in the case of CR the age of the examined patients increased, i.e. mean of 54 years (2008-2012) vs mean of 60 years (2012-2018) (10). In the ward under study, 12 cases of SSI in CR were found (incidence of 1\%). In the study carried out in the same można postawić ostrożną hipotezę, że stan zdrowia mieszkańców Tarnowa i regionu poprawia się w odniesieniu do długości lat przeżytych w zdrowiu (bez złamań). Warto zaznaczyć, że w operacjach typu FX udział kobiet był wyższy niż mężczyzn. Wiek kobiet sugeruje, że do złamań wśród kobiet dochodzi po menopauzie. Na podstawie danych z Narodowego Funduszu Zdrowia (NFZ) i Głównego Urzędu Statystycznego (GUS) w roku 2014 w Polsce zakontraktowano 63 poradnie leczenia osteoporozy, z czego 1 poradnia była w województwie małopolskim (17). Być może ma to związek z dostępnością leczenia osteoporozy dla kobiet. W piśmiennictwie brak jest jednak innych badań obrazujących badane zjawisko. W badanym oddziale rozpoznano 16 przypadków SSI w operacjach FX (zapadalność $0,8 \%$ ). W badaniach wcześniejszych przeprowadzonych przez Walaszek i wsp.. (10) w tym samym oddziale (w latach 2008-2012) zapadalność byta dużo wyższa $i$ wynosiła $3,4 \%$. W innych polskich badaniach przeprowadzonych przez Wójkowska-Mach i wsp. (18) zapadalność na SSI w FX wynosiła 1,6\%. W badanym przez nas oddziale zapadalność na SSI w FX z uwzględnieniem zmiennych typowych dla SSI (stopień czystości pola, czas operacji, skala ASA) wynosiła: 1,7\% (bez czynników ryzyka); 1\% (1 czynnik ryzyka); 0\% (2 i 3 czynniki ryzyka). W analizach prowadzonych przez Wałaszek i wsp. (10) w tym samym oddziale w latach 2008-2012 wynosiła odpowiednio: 2\% (0 czynników ryzyka); 2,6\% (1 czynnik ryzyka); $10,3 \%$ (2 i 3 czynniki ryzyka). W innym polskim badaniu przeprowadzonym w latach 2003-2004 średnia zapadalność na SSI w FX była na poziomie: 1,1\% (bez czynników ryzyka), 0,5\% (1 czynnik ryzyka), 21,4\% (2 i więcej czynników ryzyka) (18). Wskaźniki zapadalności na SSI w FX uzyskane w naszym badaniu zestawiono z wskaźnikami uzyskanymi w ramach amerykańskiego programu NHSN 2006-2008 (19) uzyskując SIR, który wykazał przekroczenie liczby jeden (SIR 1,6) w operacjach bez czynników ryzyka. Przedstawiony wskaźnik jest jednak niższy od wskaźnika uzyskanego w tym samym oddziale we wcześniejszych latach dla operacji bez czynników ryzyka SIR 1,6 (2012-2018) vs SIR 3,2 (2008-2012). Sytuacja tą można ostrożnie interpretować, jako obniżenie zapadalności na SSI w FX na skutek prowadzonego nadzoru. I choć trudno tutaj wymienić konkretne działania, których rezultatem było zmniejszenie zapadalności, można sugerować, że samo zestawienie wyników nadzoru we wcześniejszym badaniu (10) oraz zaangażowanie badanego oddziału w profilaktykę SSI mogło przyczynić się do ich obniżenia.

Dokonujac analizy operacji CR w badanym przez nas oddziale odkryto, że podobnie jak we wcześniejszym typie operacji, również w przypadku CR wydłużył się wiek badanych pacjentów; średnia 54 lata 
ward in 2008-2012, the incidence of SSI in CR was $2.2 \%$ (10). Literature review did not reveal any other publications describing SSI in the case of CR. In our study, SIR for CR did not exceed one, which means that the risk of developing SSI in such surgeries was lower than in the previous study. A limitation of this interpretation may be the fact that the results of tests, on the basis of which SIR was calculated, refer to the results from the same institution from an earlier time period. However, the incidence rate as regards CR in other centers was not found in the available literature.

Another limitation of this study may be that, despite the fact that the ward from which the SSI data came from participates in the active registration of hospital infections, in accordance with the HAI-Net methodology, the results of this program were not validated, which may explain why only SSI-D could have been detected in the institution under study, and not any other types of SSI, i.e. SSI-S or SSI-O. It seems that in spite of these limitations, it is vital to show the reader that SSIs detected in different types of orthopedic procedures can be effectively monitored in order to reduce their numbers depending on the epidemiological situation of the ward. The average time of treatment for patients undergoing $\mathrm{FX}$ or CR was longer in patients with infection, which may suggest that, regardless of the type of surgery, SSIs always resulted in a prolonged patient's stay in the ward. In the studied ward, when considering FX and CR operations, Staphylococcus aureus was the most common pathogen responsible for SSI, which means that the etiology was typical for this type of surgery.

\section{CONCLUSIONS}

1. The median age of women was higher than that of men, which may indicate an increased frequency of fractures in postmenopausal women.

2. Patients with SSI stayed in the ward longer than the ones without infection.

3. The incidence of SSI in FX and CR decreased in comparison to the previously published study concerning the same ward.

4. Staphylococcus aureus was predominant among the microorganisms isolated from SSI.

5. Reliable, everyday surveillance of SSI, taking into account epidemiological indicators, is indispensable for proper evaluation of the epidemiological situation of the ward and may have influence on the effective reduction in the number of SSIs.
(2008-2012) vs średnia 60 lat (2012-2018) (10). W badanym oddziale rozpoznano 12 przypadków SSI w CR, zapadalność $1 \%$. W badaniach przeprowadzonych w tym samym oddziale w latach 2008-2012 zapadalność na SSI w CR wynosiła 2,2\% (10). W piśmiennictwie nie znaleziono innych publikacji opisujacych SSI dla procedury CR. W naszym badaniu SIR dla CR nie przekroczył wartości jeden, co oznacza, że ryzyka powstania SSI w tego typu operacjach było mniejsze niż we wcześniejszym badaniu. Ograniczeniem tej interpretacji może być fakt, że wyniki badań na podstawie, których wyliczono SIR odnoszą się do wyników z tego samego ośrodka z lat wcześniejszych. Jednak w dostępnym piśmiennictwie nie znaleziono zapadalności dla CR w innych ośrodkach.

Pewnym ograniczeniem tego badania może być również związek z tym, że, pomimo iż oddzial, z którego pochodzą dane o SSI uczestniczy w programie czynnej rejestracji zakażeń szpitalnych, zgodnym z metodyką HAI-Net, to wyniki tego programu nie były walidowane, co może tłumaczyć, dlaczego w badanym ośrodku wykryto jedynie SSI-D, a nie wykryto innych typów SSI takich jak: SS-S i SSI-O. Wydaje się, że pomimo tych ograniczeń istotne jest pokazanie czytelnikowi, że SSI występujące w różnych typach operacji ortopedycznych można skutecznie nadzorować w celu ich obniżenia w zależności od sytuacji epidemiologicznej oddziału. Średni czas leczenia pacjentów z FX i CR był dłuższy u pacjentów z zakażeniem, co może sugerować, że niezależnie od typu zabiegu zakażenie SSI zawsze powodowało wydlużenie pobytu pacjenta w oddziale. W badanym oddziale dla operacji typu FX i CR najczęstszym patogenem odpowiedzialnym za SSI był Staphylococcus aureus, czyli etiologia typowa w przypadku operacji tego typu.

\section{WNIOSKI}

1. Mediana wieku kobiet była wyższa niż mężczyzn, co może wskazywać na częstsze występowanie złamań u kobiet w okresie po menopauzie.

2. Pacjenci, u których stwierdzono SSI mieli dłuższy pobyt w oddziale niż bez zakażenia.

3. Zapadalność na SSI w FX i CR uległa zmniejszeniu $\mathrm{w}$ porównaniu z z danymi we wcześniejszej publikacji.

4. Wśród drobnoustrojów izolowanych SSI dominował Staphylococcus aureus.

5. Prowadzenie rzetelnego, codziennego nadzoru nad SSI z uwzględnieniem wskaźników epidemiologicznych jest konieczne, aby właściwie ocenić sytuacje epidemiologiczną oddziału i może wpływać na efektywne obniżenie liczby SSI. 


\section{REFERENCES}

1. Global guidelines for the prevention of surgical site infection, second edition. Geneva: World Health Organization; 2018. https://apps.who.int/ iris/handle/10665/250680

2. Piątkowska E, Mazurkiewicz J, Bartoszewicz M. Profilaktyka zakażeń miejsca operowanego przegląd aktualnych wytycznych. Forum Zakażeń. 2018; 9;2: 91-5.

3. Bloch-Bogusławska E, Wolska E, Engelgardt P, et al. Bakteryjne zakażenia szpitalne w latach 20002006 w materiałach własnych Katedry Medycyny Sądowej CM UMK w Bydgoszczy. Archiwum Medycyny Sadowej i Kryminologii. 2008; LVIII: 22-26

4. Nowicka J, Bartoszewicz M. Zakażenia w ortopedii związane ze stosowaniem biomateriałów. Post Mikrobiol 2015; 54 (4): 320-330.

5. Nowacki J, Dobrzański L, Gustavo F. Implanty śródszpikowe w osteosyntezie kości długich. Open Access Library, 2012.

6. Mabit C, Marcheix P, Mounier M, et al. Impact of a surgical site infection (SSI) surveillance program in orthopedics and traumatology. Orthopaedics \& Traumatology: Surgery \& Research 2012; 98 (6): 690-695.

7. Liang $\mathrm{Z}$, Rong $\mathrm{K}, \mathrm{Gu} \mathrm{W}$, et al. Surgical site infection following elective orthopaedic surgeries in geriatric patients: Incidence and associated risk factors. International Wound Journal 2019; doi: 10.1111/iwj.13096. [Epub ahead of print]

8. Al-Mulhim FA, Baragbah MA, Sadat-Ali M, et al. Prevalence of surgical site infection in orthopedic surgery: a 5-year analysis. International Surgery 2014; 99 (3): 264-268.

9. Maksimović J, Marković-Denić L, Bumbaširević $\mathrm{M}$, et al. Surgical Site Infections in Orthopedic Patients: Prospective Cohort Study. Croatian Medical Journal 2008; 49 (1): 58-65.

10. Wałaszek M, Zieńczuk W, WolakZ, et al.Zakażenia miejsca operowanego u pacjentów oddziału ortopedyczno-urazowego szpitala wojewódzkiego zarejestrowane w latach 2008-2012. Przegląd Epidemiologiczny 2013; 67: 543-546.

11. Kołpa M, Wałaszek M, Różańska A, et al. HospitalWide Surveillance of Healthcare-Associated Infections as a Source of Information about Specific Hospital Needs. A 5-Year Observation in a Multiprofile Provincial Hospital in the South of Poland. Int J Environ Res Public Health 2018; 15(9): 1956.

12. Pawłowska I, Ziółkowski G, Wójkowska-Mach $\mathrm{J}$, et al. Can surgical site infections be controlled through microbiological surveillance? A three-year laboratory-based surveillance at an orthopaedic unit, retrospective observatory study. International Orthopaedics. 2019; 1-8.

13. Babiak I, Górecki A. Zakażenia szpitalne na oddziale chirurgii ortopedycznej - pacjenci dorośli. In: Bulanda M (ed.). Zakażenia Szpitalne na Oddziałach Zabiegowych. Polskie Towarzystwo Zakażeń Szpitalnych, Kraków, 2008, pp. 145- 161.

14. Wałaszek M, Wolak Z, Dobroś W. Nosocomial infection in patients hospitalized in 2005-2011. the St. Lukas District Hospital in Tarnów. Przegląd Epidemiologiczny 2012; 66 (4): 617-621.

15. European Center for Disease Prevention and Control. Point prevalence survey of healthcare - associated infections and antimicrobial use in European acute care hospitals - protocol version 4.3. Stockholm, ECDC; 2012. http://ecdc.europa.

16. European Centre for Disease Prevention and Control. Surveillance of surgical site infections and prevention indicators in European hospitals -HAI-Net SSI protocol, version 2.2.Stockholm: ECDC; 2017.

17. Marcinowska-Suchowierska E, Głuszko $P$, Badurski J, et al. Leczenie farmakologiczne osteoporozy w Polsce - dostępność, przyczyny braku jego wdrażania. Postępy Nauk Medycznych 2015; 23(12):879-885.

18. Wójkowska-Mach J, Bulanda M, Kochan P et al. Nadzór nad zakażeniami miejsca operowanego i zarządzanie jakością w polskich szpitalach. Chirurgia Polska 2006;8(2):136-145.

19. Edwards J, MStat, Peterson K, et al. National Healthcare Safety Network (NHSN) report: Data summary for 2006 through 2008, issued December 2009. American Journal of Infection Control. 2009; 37: 783-805.

Received:23.01.2020

Otrzymano:23.01.2020

Accepted for publication: 24.06.2020 r.

Zaakceptowano do publikacji:24.06.2020 r.

\section{Correspondence address:} Adres do korespondencji:

Marta Wałaszek

Szpital Wojewódzki im. Św. Łukasza

33-100 Tarnów, ul. Lwowska 178a

Tel. 146315321

e-mail:mz.walaszek@gmail.com 